\title{
Fly ash as the component of composites materials
}

\author{
M. Prascakova ${ }^{1^{*}}$, M. Kusnierova ${ }^{1}$, V. Cablik ${ }^{2}$, A. Jarosiński ${ }^{3}$ \\ ${ }^{1}$ Slovak Academy of Sciences, Institute of Geotechnics, Watsonova 45, 04353 Kosice, Slovakia \\ ${ }^{2}$ VŠB - Technical University of Ostrava, ICT - Institute of Clean Technologies for Mining and Utilization of Raw Materials \\ for Energy Use 17. listopadu, 70833 Ostrava-Poruba, Czech Republic \\ ${ }^{3}$ Polish Academy of Sciences, Mineral and Energy Economy Research Institute, ul. J. Wybickiego 7, 31-261 Kraków, Poland \\ "Corresponding author: prascak@saske.sk
}

\begin{abstract}
The fly ash from powerplant can be compared, due to its genesis, chemical and mineralogical composition with the natural volcanic glasses and minerals generated in the process of devitrification in situ. Its quality is comparable to non-metallic alumosilicate raw materials that are commercially used in building and ceramic industry. Two possibilities of fly ash utilization as the most bulk waste produced by anthropogenic activity were examined.

The way of fly ashes utilization in the modeling of mixtures for the high refractory mullite corundum materials synthesis was examined. In this experiment $95.5 \%$ conversion of the input components of fly ash and $\mathrm{Al}$ additive in the ratio 1:1 on the mullite and corundum was obtained.
\end{abstract}

Keywords: black coal fly ash, mullitization, technolithes.

\section{INTRODUCTION}

Increase of the technogenous wastes content exceeds the auto regeneration ability of the nature. Exhausting of the primary raw materials and wastes production has reached the critical level, and it is necessary to include the wastes of useful components content in the raw materials cycle. This is the aspect of the new interdisciplinary geosciences-technical branches of research that are known as material engineering and technolithology ${ }^{1}$.

Technolithology is especially focused on the geosciences-technical area and also works on adding the wastes to the earth's material cycle in the form of the newly produced composites and technolithes ${ }^{2}$. Many of the technolithes have their natural equivalents. One of the examples are fly ashes that are similar, because of their genesis and composition, to the volcanic ashes and from them created the alumo-silicate minerals. It is therefore anticipated that also the areas of their utilization could be similar and in technologies could partially substitute raw materials. The basic characteristics which allow including the examined fly ashes in the earth's material cycle are connected, particularly with the possibility of fly ashes Si-Al matrix utilization for the refractory technolithes development.
The results from the research on the rational fly ashes from the heating plant TEKO inc. Kosice, Slovakia, utilization focused on its application by developing the new type of refractory technolithe of mullite-corundum type, were presented.

In nature mullite is created in the zones rich in $\mathrm{Al}$, above all in the sillmanite, andalusite, cyanite and topaz form, as a result of its contact with high temperatures of lava streams. The temperature of thermal transformation of the mentioned alumosilicates to mullite is around $1300^{\circ} \mathrm{C}^{3}$. Also other alumosilicates should be transformed to mullite, e. g. talc $c^{4-6}$ but only in the suitable stoichiometric ratio of $\mathrm{Al}$ and $\mathrm{Si}$ that is $3: 2^{7-9}$. Industrially the bulk of the mullite production comes from kaolinite and synthetic $\mathrm{Al}_{2} \mathrm{O}_{3}$. The composition of the commercially used refractory materials produced and used in industry is practically never of mono-mineral composition. In table 1 examples of the commercially produced refractory materials are shown ${ }^{\mathbf{1 0}}$.

Following the data shown in table 1 it is evident that for the new technolithes on the fly ash basis creation the content of $\mathrm{Al}_{2} \mathrm{O}_{3}$ and the ratio of the majority components of technolithe, $\mathrm{Al}_{2} \mathrm{O}_{3}$ and $\mathrm{SiO}_{2}$ are important. The second important factor is the process of thermal transformation of mullite and corundum.

Table 1. Commercially produced refractory materials, raw materials, mineral compositions and the areas of their utilization, after Gregerova $^{10}$

\begin{tabular}{|c|c|c|c|c|}
\hline $\begin{array}{l}\text { Refractory } \\
\text { technolithes }\end{array}$ & $\begin{array}{l}\text { Mineral composition of base } \\
\text { crude }\end{array}$ & Mineral composition of technolithe & $\begin{array}{l}\text { Abundance of basic } \\
\text { oxides }\end{array}$ & $\begin{array}{l}\text { Temperature } \\
\text { resistance - utilization }\end{array}$ \\
\hline Silica chamotte & $\begin{array}{l}\text { kaoline, claystone, clay, } \\
\text { quartz sand }\end{array}$ & $\begin{array}{l}\text { mullite, cristobalite, tridymite, } \\
\text { quartz }\end{array}$ & $10-30 \% \mathrm{Al}_{2} \mathrm{O}_{3}$ & up to $1670^{\circ} \mathrm{C}$ \\
\hline Clay chamotte & Refractory clays, claystones & mullite & $35-45 \% \mathrm{Al}_{2} \mathrm{O}_{3}$ & up to $1750^{\circ} \mathrm{C}$ \\
\hline $\begin{array}{l}\text { High clayey } \\
\text { chamotte }\end{array}$ & $\begin{array}{l}\text { Refractory clays, claystones, } \\
\text { hydroxides and oxides, } \mathrm{Al} \\
\text { minerals } \mathrm{Al}_{2} \mathrm{SiO}_{5}\end{array}$ & mullite, cristobalite, corundum & $\begin{array}{l}45-60 \% \mathrm{Al}_{2} \mathrm{O}_{3} \\
60-75 \% \mathrm{Al}_{2} \mathrm{O}_{3} \\
\text { over } 75 \% \mathrm{Al}_{2} \mathrm{O}_{3}\end{array}$ & $\begin{array}{l}\text { up to } 1840^{\circ} \mathrm{C} \\
\text { up to } 1900^{\circ} \mathrm{C} \\
\text { up to } 1950^{\circ} \mathrm{C}\end{array}$ \\
\hline $\begin{array}{l}\text { Mullite refractory } \\
\text { technolithes }\end{array}$ & $\begin{array}{l}\text { Al hydroxides and oxides, } \\
\text { sillimanite, andalusite, } \\
\text { cyanide }\end{array}$ & mullite, cristobalite, corundum & $60-85 \% \mathrm{Al}_{2} \mathrm{O}_{3}$ & up to $1960^{\circ} \mathrm{C}$ \\
\hline $\begin{array}{l}\text { Examined waste fly } \\
\text { ash }\end{array}$ & $\begin{array}{l}\text { Black coal with accessory } \\
\text { rocks }\end{array}$ & $\begin{array}{l}\text { amorphous vitric phases Si-Al, } \\
\text { quartz, cristobalite, mullite, } \\
\text { corundum, feldspars, unburned } \\
\text { coal, hematite, maghemite, } \\
\text { graphite, montmorillonite, } \\
\text { tobermorite, hydrargillite-gibbsite }\end{array}$ & $\begin{array}{l}\mathrm{Al}_{2} \mathrm{O}_{3} 20.86 \% \\
\mathrm{SiO}_{2} 47.10 \%\end{array}$ & $\begin{array}{l}\text { As refractory material } \\
\text { inapplicable without } \\
\text { pretreatment! }\end{array}$ \\
\hline
\end{tabular}




\section{MATERIALS AND METHODS}

\section{Fly ash}

Black coal fly ash from the heating plant TEKO Kosice without treatment, of the chemical composition shown in table 2, was examined.

From the XRD analysis of the fly ash sample it was found that the dominant phase in the fly ash is the amorphous vitric phase. Then the minerals such as: quartz, cristobalite, anhydrite, feldspar, corundum, magnetite, hematite and graphite were identified.

Thermal properties of the examined fly ash are as follows: by $1230^{\circ} \mathrm{C}$ softening, by $1270^{\circ} \mathrm{C}$ thawing and over $1270^{\circ} \mathrm{C}$ fluxing.

\section{Al additive}

As $\mathrm{Al}$ additive $(\mathrm{G})$ pure $\mathrm{Al}(\mathrm{OH})_{3}$ - gibbsite (hydrargillite) with the content of $\mathrm{Al}_{2} \mathrm{O}_{3} \quad 65.3 \%$ and $\mathrm{H}_{2} \mathrm{O}$ $34.7 \%$ was used. Gibbsite is changed during the thermal treatment at $196-202^{\circ} \mathrm{C}$ to boehmite $\mathrm{AlO}(\mathrm{OH})$, at $950^{\circ} \mathrm{C}$ is disintegrated and creates $\gamma \mathrm{Al}_{2} \mathrm{O}_{3}{ }^{4}$.

The composite mixtures preparation was focused on 3 different mixing ratios of the fly ash and gibbsite (ratios 2:1, 1.5:1 and 1:1). With these ratios the similar stoichiometric ratios of $\mathrm{Al}_{2} \mathrm{O}_{3}$ and $\mathrm{SiO}_{2}$ similar to mullet were anticipated. The mixtures of both components were consequently homogenized in the planetary mill for 10 minutes. The prepared mixtures products were thermally modified by the temperatures of 850,1050 and $1500^{\circ} \mathrm{C}$. The obtained new materials were thereafter analyzed for the mullite and corundum components that are the basic for the refractory materials.

The process of thermal transformation by $0,850,1050$ and $1500^{\circ} \mathrm{C}$ was evaluated by XRD analysis. The inert standard-pure $\mathrm{ZnO}$ (c. 5 weight $\%$ ) was added to the process of mullitization with the aim to quantify the amorphous components and the new-produced phases in the composite mixtures. The samples were homogenised with this standard by micro-milling and consequently boxed up in the glass cuvette.

The measurement was provided by the full automatic diffraction meter URD-6 (Rich Seifert-FPM, Germany) under the following conditions: emission of CoKa/ Ni rejecter, potential of $40 \mathrm{kV}$, ampere of $35 \mathrm{~mA}$, step mode $0.05^{\circ} 2 \Theta$ with the step time of $3 \mathrm{~s}$ and the digital processing of the measured data. For the measuring and results evaluation software RayfleX (RayfleX ScanX and RayfleX Analyze, 2.289 version) was used.

\section{RESULTS AND DISCUSSION}

With regard to the phases composition, the elementary qualitative-quantitative parameters of the prepared composite materials are shown in table 4 and in figures $1-3$. The results of the thermal transformation of basic fly ash components are shown in table 3. As a result of the temperature influence, the content of the amorphous phases of the fly ash decreased. There was a momentary decrease of mullite contents at the temperature of the $850^{\circ} \mathrm{C}$, thereupon the metstabile corundum structures were formed. However, with the increase of the temperature to $1050^{\circ} \mathrm{C}$, the mullite content increased to the double value of the original sample. The total content of the refractory components increased to $1050^{\circ} \mathrm{C}$. At higher temperatures the treated sample was totally melted and devaluated.

In table 4 and figures 1-3 the experimental results of the thermal transformation of composite mixtures of the fly ash and gibbsite milled for 10 minutes in the planetary mill, are presented. The temperature influence and the mixing ratio of the fly ash and gibbsite on the mullite corundum phases creation in the newly prepared technolithes was monitored.

The course of the phases changes by the thermal processing of the composite mixtures of the fly ash and gibbsite in the $2: 1,1.5: 1,1: 1$ mixing ratios are shown in figures 1-3.

Following the comparison of the results showed in table 4 and figures $1-3$, it is possible to say that at $850^{\circ} \mathrm{C}$ in all

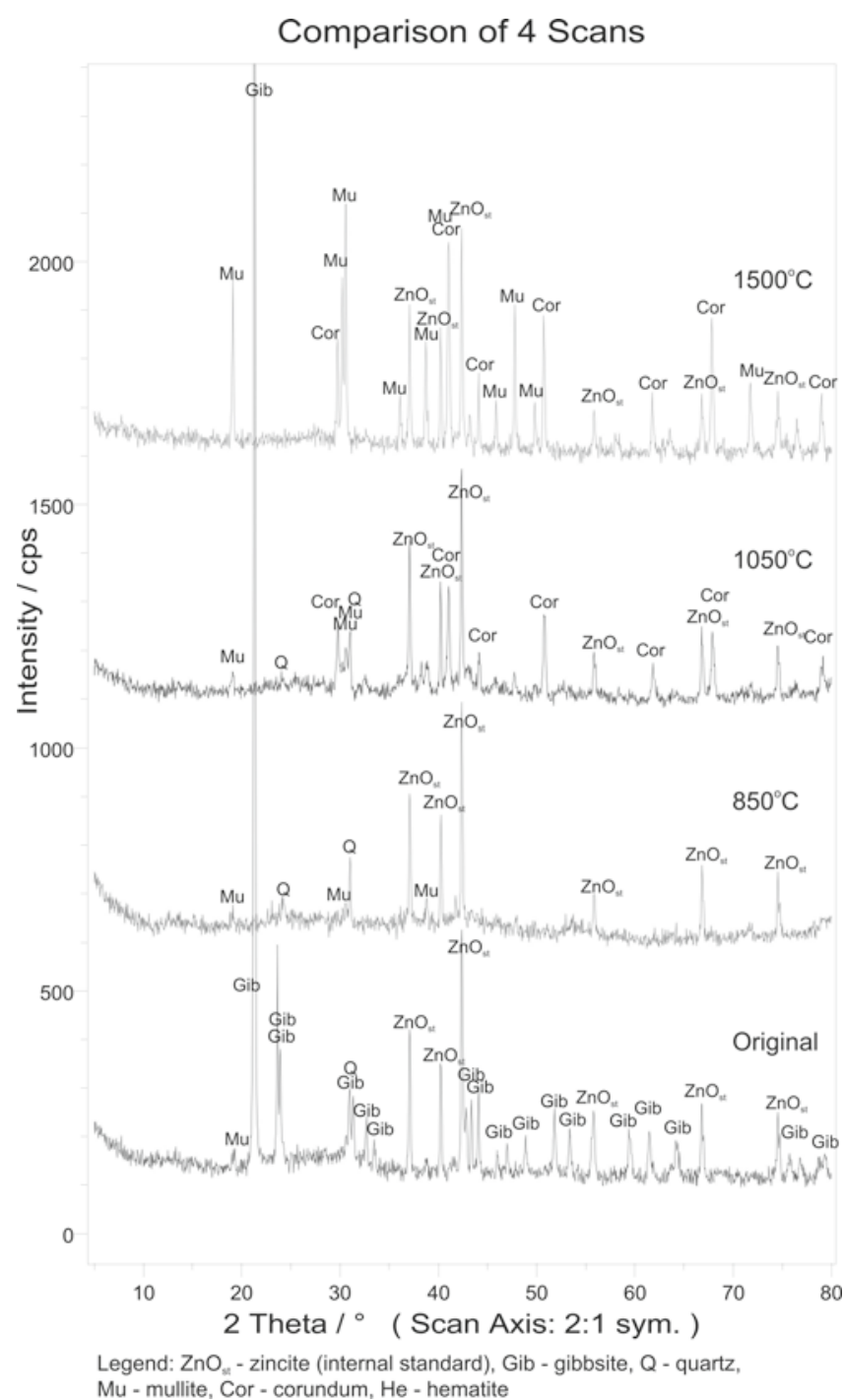

Figure 1. Phases changes by the thermal processing of the composite mixture in the ratio $1: 1$

Table 2. Chemical composition of examined fly ash (P)

\begin{tabular}{|c|c|c|c|c|c|c|c|c|c|c|c|}
\hline $\begin{array}{c}\text { Annealing lost } \\
(\%)\end{array}$ & $\begin{array}{l}\mathrm{SiO}_{2} \\
(\%)\end{array}$ & $\begin{array}{c}\mathrm{Al}_{2} \mathrm{O}_{3} \\
(\%)\end{array}$ & $\begin{array}{c}\mathrm{Fe}_{2} \mathrm{O}_{3} \\
(\%)\end{array}$ & $\begin{array}{c}\mathrm{CaO} \\
(\%)\end{array}$ & $\begin{array}{l}\mathrm{TiO}_{2} \\
(\%)\end{array}$ & $\begin{array}{c}\mathrm{MgO} \\
(\%)\end{array}$ & $\begin{array}{c}\mathrm{Na}_{2} \mathrm{O}_{3} \\
(\%)\end{array}$ & $\begin{array}{l}\mathrm{K}_{2} \mathrm{O} \\
(\%)\end{array}$ & $\begin{array}{l}\mathrm{P}_{2} \mathrm{O}_{5} \\
(\%)\end{array}$ & $\begin{array}{l}\mathrm{S}_{\text {total }} \\
(\%)\end{array}$ & $\mathrm{pH}$ \\
\hline 15.5 & 47.10 & 20.86 & 8.83 & 23.80 & 0.76 & 1.21 & 0.78 & 2.14 & 0.35 & 0.15 & 12.4 \\
\hline
\end{tabular}


Table 3. The influence of thermal transformation on the phase's composition of examined fly ash

\begin{tabular}{|c|c|c|c|c|c|}
\hline \multirow{2}{*}{$\begin{array}{c}\text { Mixing ratio } \\
\text { P:G }\end{array}$} & Transformation temperature $\left({ }^{\circ} \mathrm{C}\right)$ & \multicolumn{4}{|c|}{ Content (\%) } \\
\cline { 2 - 6 } & & Amorphous phases & Mullite & Corundum & Refractory material \\
\hline \multirow{3}{*}{$1: 0$} & 0 & 83.05 & 10.66 & - & 10.66 \\
\cline { 2 - 6 } & 850 & 72.3 & 9.29 & 2.96 & 12.25 \\
\cline { 2 - 6 } & 1050 & 64.3 & 22.7 & - & 22.7 \\
\cline { 2 - 6 } & 1500 & \multicolumn{4}{|c|}{ Sample was melted and devaluated } \\
\hline
\end{tabular}

Table 4. The qualitative-quantitative composition of prepared technolithes of mullite-corundum type

\begin{tabular}{|c|c|c|c|c|c|c|}
\hline \multirow{2}{*}{$\begin{array}{l}\text { Mixing ratio } \\
P: G\end{array}$} & \multirow{2}{*}{$\begin{array}{l}\text { Transformation temperature } \\
\qquad\left({ }^{\circ} \mathrm{C}\right)\end{array}$} & \multicolumn{5}{|c|}{ Content (\%) } \\
\hline & & Amorphous phases & Mullite & Corundum & $\begin{array}{l}\text { Refractory } \\
\text { material }\end{array}$ & $\mathrm{Al}_{2} \mathrm{O}_{3}$ \\
\hline \multirow{4}{*}{$2: 1$} & 0 & 50.5 & 6.79 & - & 6.79 & \\
\hline & 850 & 86.2 & 4.82 & 0.85 & 5.67 & \\
\hline & 1050 & 69.2 & 14.54 & 7.45 & 21.99 & \\
\hline & 1500 & 39.8 & 56.8 & 2.35 & 59.15 & 35.60 \\
\hline \multirow{4}{*}{$1.5: 1$} & 0 & 37.4 & 4.61 & - & 4.61 & \\
\hline & 850 & 88.95 & 3.84 & 0.54 & 4.38 & \\
\hline & 1050 & 63.0 & 14.3 & 13.3 & 27.6 & \\
\hline & 1500 & 21.5 & 63.8 & 13.3 & 77.1 & 40.01 \\
\hline \multirow{4}{*}{$1: 1$} & 0 & 30.0 & 5.4 & - & 5.4 & \\
\hline & 850 & 86.58 & 3.96 & 1.44 & 5.4 & \\
\hline & 1050 & 54.0 & 12.7 & 23.9 & 36.6 & \\
\hline & 1500 & 2.1 & 59.0 & 38.9 & 97.9 & 43.13 \\
\hline
\end{tabular}

Comparison of 4 Scans

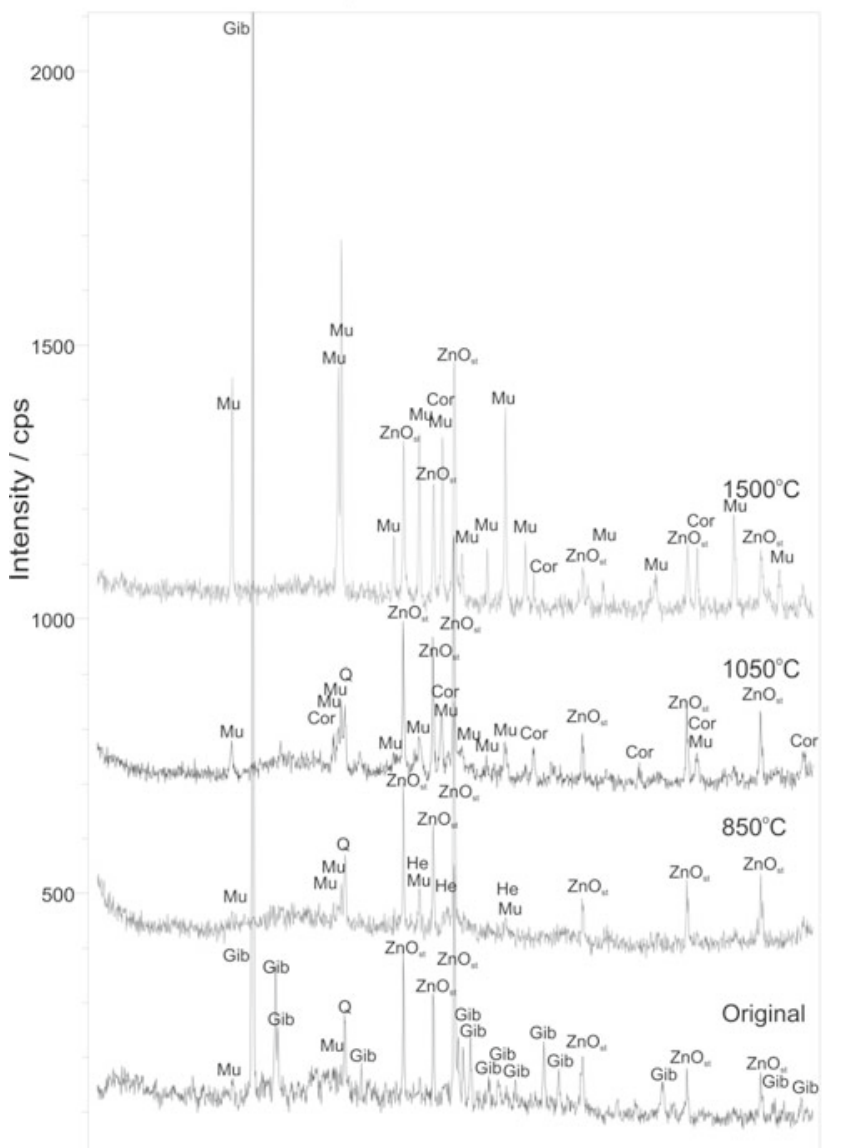

0

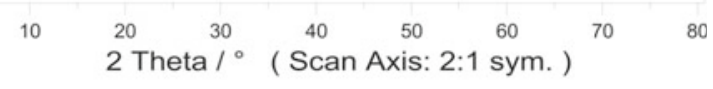

Legend: $\mathrm{ZnO}_{\mathrm{s}}$ - zincite (internal standard), Gib - gibbsite, Q - quartz,

$\mathrm{Mu}$ - mullite, Cor - corundum, $\mathrm{He}$ - hematite

Figure 2. Phases changes by the thermal processing of the composite mixture in the ratio $2: 1$
3000

Comparison of 4 Scans

Gib

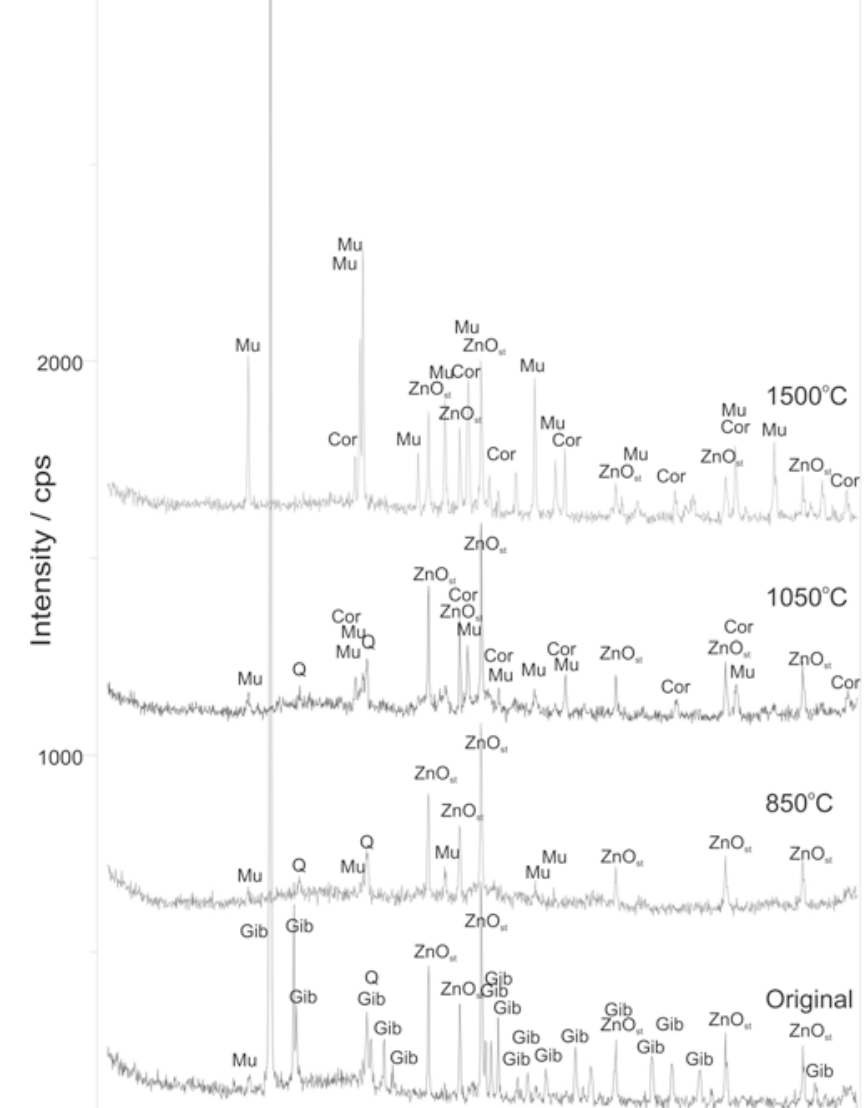

0

$\begin{array}{llllllll}10 & 20 & 30 & 40 & 50 & 60 & 70 & 80\end{array}$

2 Theta $^{\circ}$ (Scan Axis: 2:1 sym. )

Legend: $\mathrm{ZnO}_{\mathrm{s}}$ - zincite (internal standard), Gib - gibbsite, Q - quartz,

$\mathrm{Mu}$ - mullite, Cor - corundum, $\mathrm{He}$ - hematite

Figure 3. Phases changes by the thermal processing of the composite mixture in the ratio $1.5: 1$ 
the experiments a sharp increase of the amorphous phases content and in the content of refractory components in the case of the gibbsite dehydration was noted. With the continual increase of the temperature, the content of the refractory components rose from $6.79 \%$ to $20-36.6 \%$ at $1050^{\circ} \mathrm{C}$ up to $59-97.5 \%$ at $1500^{\circ} \mathrm{C}$.

During the mullite phases creation there was the optimal fly ash and gibbsite ratio of $1.5: 1$, where at $1500^{\circ} \mathrm{C}$ the technolite of $63.8 \%$ mullite content was prepared.

During the corundum phases creation with the optimal conditions in the 1:1 ratio and the temperature of $1500^{\circ} \mathrm{C}$, the maximal corundum content of $38.9 \%$ was achieved. Under the same conditions the maximal sum of both refractory components in the prepared technolithe, namely $97.9 \%$, was obtained.

With respect to the commercial categorization of the refractory materials and its $\mathrm{Al}_{2} \mathrm{O}_{3}$ content (see table 4) it is possible to integrate the prepared technolithes to the category of "normal chamotte" of $1750^{\circ} \mathrm{C}$ refractoriness.

\section{CONCLUSION}

The presented results confirmed that the examined black coal fly ashes are wrongly classified as waste. The possibility of its effective usage by the preparation of new materials and technolithes that have good household properties has been confirmed. This is only one of the examples of the possible way of the examined fly ash utilization. In industrial production fly ashes should substitute part of the primary raw materials with the positive impact on the economics and environment. This is only the question of the focused research to find the most suitable application of this waste material by creating the new composite materials and technolithes.

\section{ACKNOWLEDGEMENT}

This research has been carried out within the SGA project No. 2-0086-10, SRDA projects No. SK-PL-0048-09, No. SK-CZ-0146-09 and mobility project No. MEB0810142.

\section{LITERATURE CITED}

1. Gregerova, M. (2007). Technolithology, present and future prospect. Acta Geologica Universitatis Comenianae, 1 (1), 7.

2. Gregerova, M., Fojt, B. \& Vavra, V. (2002). Microscopy of rock-forming and technical minerals. Moravian museum, Masaryk University Brno, Faculty of Science, 325, [in Czech].

3. Mason, B. \& Berry, L.G. (1968). Elements of mineralogy. W. H. Freeman and Company, San Francisco, 550.

4. Dana, K., Das, S. \& Kumar, D.S. (2004). Effect of substitution of fly ash for quartz in triaxial kaolin-quartz-feldspar system. Journal of the European Ceramic Society, 24 (10-11), 3169-3175. DOI:10.1016/j.jeurceramsoc.2003.10.008.

5. Yong, H., Weimin, Ch. \& Hesheng, C. (2005). Characterization of $\alpha$-cordierite glass-ceramics from fly ash. Journal of Hazardous Materials, 120 (1-3), 265-269. DOI:10.1016/j. jhazmat.2004.10.028.

6. Kusnierova, M., Prascakova, M., Matysek, D., Cablik, V. \& Jarosinski, A. (2010). Black coal fly ash as the Si-Al matrix for the heat proof materials preparation. Mineralia Slovaca, 42 (3), 323-328.

7. Hankyr, V. \& Kutzendorfer, J. (2008). Technology of ceramics. Silica society, Praha, 387, [in Czech].
8. Jung, J.S., Park, H.C. \& Stevens, R. (2001). Mullite ceramics derived from coal fly ash. Journal of Materials Science Letters, 20 (12), 1089-1091. DOI: 10.1023/A:1010934728570.

9. Mukhopadhyay, T.K., Ghosh, S., Ghosh, J., Ghatak, S. \& Maiti, H.S. (2010). Effect of fly ash on the physico-chemical and mechanical properties of a porcelain composition. Ceramics International, 36 (3), 1055-1062. DOI:10.1016/j. ceramint.2009.12.012.

10. Gregerova, M. (2004). Technolithology, Institute of geological Sciences, Faculty of Science, Masaryk University Brno, 74. 